\title{
CORROSION RESISTANCE OF HIGH PRESSURE TORSION OBTAINED COMMERCIALLY PURE TITANIUM IN ACIDIC SOLUTION
}

\author{
Dragana R. Barjaktarević, Ivana D. Dimić, Ivana Lj. Cvijović-Alagić, Đorđe N. Veljović, Marko P. Rakin
}

Original scientific paper

The enhancement of commercially pure titanium (cpTi) mechanical properties, which is required for its medical application, can be achieved by grain refinement obtained by severe plastic deformation. In addition to mechanical properties improvement, excellent corrosion resistance of ultrafine-grained (UFG) cpTi in contact with human body fluids is required. Therefore, the aim of this study was to estimate electrochemical behavior of UFG cpTi obtained by high pressure torsion (HPT) under a pressure of 7,8 GPa at room temperature and up to 5 rotations. Electrochemical measurements were performed in artificial saliva at $37^{\circ} \mathrm{C}$ in order to simulate oral environment, since development of UFG cpTi is primarily aimed for dental implant applications. Electrochemical behavior of UFG cpTi was investigated by electrochemical impedance spectroscopy (EIS) and potentiodynamic polarization. The obtained results indicate that HPT process, through significant grain size reduction, increases corrosion resistance of $\mathrm{cpTi}$.

Keywords: artificial saliva; corrosion resistance; electrochemical measurements; ultrafine-grained titanium

\section{Otpornost na koroziju u kiseloj otopini komercijalno čistog titana dobivenog uvijanjem pod visokim tlakom}

Izvorni znanstveni članak

Poboljšanje mehaničkih svojstava komercijalno čistog titana (cpTi), koje je neophodno za njegovu medicinsku primjenu, može se postići usitnjavanjem mikrostrukture primjenom procesa jakog plastičnog deformiranja. Osim poboljšanih mehaničkih svojstava, neophodna je odlična korozijska otpornost sitnozrnog (UFG) cpTi u kontaktu s tjelesnim tekućinama. Stoga je cilj ovog istraživanja bio procijeniti elektorokemijsko ponašanje UFG cpTi dobivenog primjenom procesa uvijanja pod visokim tlakom (HPT) primjenom tlaka od 7,8 GPa na sobnoj temperaturi i pri 5 okretaja. Elektrokemijska mjerenja su provedena u umjetnoj slini na $37^{\circ} \mathrm{C}$ kako bi se simuliralo oralno okruženje, jer se UFG cpTi prvenstveno razvija za primjenu u stomatologiji i za izradu dentalnih implantata. Elektrokemijsko ponašanje UFG cpTi je istraživano spektroskopijom elektrokemijske impedancije (SEI) i potenciodinamičkom polarizacijom. Dobiveni rezultati pokazuju da HPT proces, kroz značajno smanjenje veličine zrna, povećava otpornost cpTi prema koroziji.

Ključne riječi: elektrokemijska mjerenja; otpornost prema koroziji; sitnozrni titan; umjetna slina

\section{Introduction}

Commercially pure titanium (cpTi) is the most commonly used metallic biomaterial. Numerous applications of titanium can be found in biomedicine, for instance, in devices for artificial hearts, structural applications such as screws and dental implant pins, and dental and orthopedic prostheses [1]. There is a requirement that the biomaterials have high mechanical strength, low elastic modulus, excellent biocompatibility and high corrosion resistance $[1,2]$. To determine the suitability of a metallic material for implant applications in the human body, several properties must be evaluated. Among these properties, the corrosion behavior is of crucial interest, because the metallic ion release from the implant to the surrounding tissues and organs may give rise to biocompatibility problems [3]. The corrosion resistance of metallic materials is very important property which has significant influence on possibility of material use in biomedicine as well as in many other applications areas [4-6]. For example, pipelines for gas, oil and hotwater transport are used usually for a longer period of time in underground exploitation; such pipelines are subjected to damage under external environmental conditions, which can lead to corrosion. The corrosion mass-loss decreases the cross-section of the pipe at the point of damage, which leads to the failure of the pipeline [6].

The corrosion resistance is of great importance, not only because it determines the medical and dental device's useful life, but also due to the harmfulness of corrosion processes taking place in the living organism which may lead to corrosion products release and affect cell metabolism [7-10]. It should be noted that under normal conditions, human body fluids are $0,9 \%$ saline solutions containing amino acids and proteins, with $\mathrm{pH}$ value about 7,0 (although $\mathrm{pH}$ value may fall to $4-5$ due to inflammation caused by surgery or injury), while temperature and pressure values are $37^{\circ} \mathrm{C}$ and 1 atm $(1,01325$ bar $)$, respectively $[11,12]$. In addition to their exposure to chemically aggressive environment, dental implants are also exposed to high mechanical stresses, e.g. during chewing cycle.

According to the all above mentioned it can be concluded that the human body presents a chemically and mechanically harsh environment for metallic materials, and therefore it can influence and reduce the consistency of biocompatibility and corrosion resistance of metallic implant materials. It should be mentioned that cpTi shows very good corrosion resistance in diverse media due to the formation of passive $\mathrm{TiO}_{2}$ thin film on its surface upon exposure to air, while cpTi corrosion rate is found to be significant in concentrated acid solutions at room temperature since the protective oxide film tends to dissolve in aggressive media [13]. In addition, metallic materials can generate metallic ions, which react with the human body fluid, especially with chloride ions forming complex compounds and precipitates. They also can form hydroxides or oxides when in contact with water and produce the local change of the solution $\mathrm{pH}$. These $\mathrm{pH}$ value changes can generate potential and current gradients; hence the possibility of the local acceleration of the corrosion on some areas of the implant exists. Moreover, during inflammatory process, the $\mathrm{pH}$ value can vary from 5,4 to 7,8 [14]. It is interesting to note that 
formation rate and protective properties of the passive film layer are dependent on the environmental conditions.

Although cpTi is considered to be one of the best biocompatible metallic materials for dental applications, because its surface properties result in the spontaneous formation of a stable passive oxide layer, it does not have high enough strength $[3,8,15]$. Therefore, different thermo-mechanical treatments and alloying processes had been examined in order to improve mechanical properties of cpTi. However, it is known that further enhancement of mechanical properties of metallic materials may be achieved by severe plastic deformation (SPD) processes, leading to the formation of finer microstructures [16]. Large numbers of different SPD methods, such as equal channel angular pressing (ECAP) and high pressure torsion (HPT) and other similar processes, have been extensively studied in recent years [16-18]. HPT is very attractive SPD method where deformation is obtained mainly by simple shear. This method applies very large strains in a material due to the applied hydrostatic pressure during deformation. Schematic overview of HPT process is presented in Fig. 1. The HPT technique has several advantages compared to ECAP: (1) it is a relatively simple technique, (2) it is more effective in producing smaller grains, (3) it produces a higher fraction of boundaries with high misorientation angles, and (4) it provides the capability of advanced consolidation of fine particles and amorphous ribbons [19].

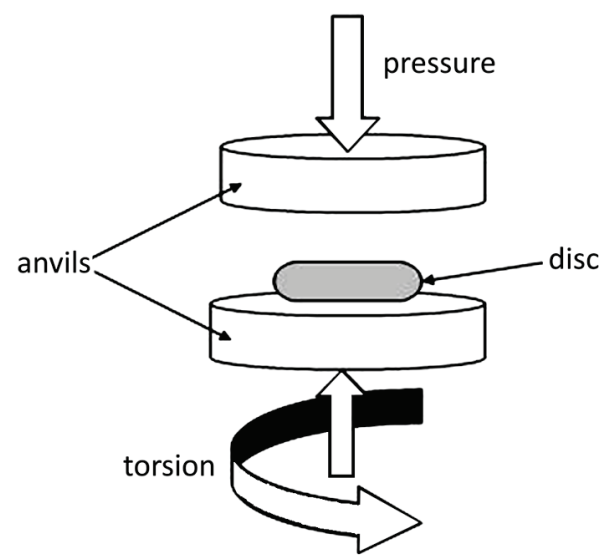

Figure 1 Schematic overview of HPT processes

An equivalent strain $(\varepsilon)$ imposed on the sample depends on the number of rotations $(N)$, the radius $(r)$ and the thickness $(t)$ of the sample obtained by HPT process, as can be seen from the following equation [17]:

$\varepsilon=\frac{2 \pi \cdot N \cdot r}{\sqrt{3 t}}$.

Generally, ultrafine-grained (UFG) metals and alloys produced by SPD techniques have better mechanical and physical properties compared to their coarse-grained (CG) counterparts. There are numerous studies about mechanical and physical properties of UFG cpTi produced by SPD techniques [20, 21], but only a few about corrosion resistance of this material [22-24]. Moreover, most of the studies investigated UFG cpTi produced by ECAP [25]. Therefore, the purpose of this study was to evaluate corrosion resistance of UFG cpTi obtained by HPT process and to estimate the effect of $\mathrm{pH}$ value on corrosion rate of cpTi with UFG and CG microstructures.

\section{Materials and methods}

The chemical composition of cpTi grade 2 (supplied by Goodfellow, Germany) is given in Tab. 1 .

Table 1 Chemical composition of cpTi used in this study (\% weight)

\begin{tabular}{|l|c|c|c|c|c|}
\hline $\mathrm{C}$ & $\mathrm{H}$ & $\mathrm{N}$ & $\mathrm{O}$ & $\mathrm{F}$ & $\mathrm{Ti}$ \\
\hline 0,10 & 0,015 & 0,03 & 0,25 & 0,30 & Bal. \\
\hline
\end{tabular}

The cpTi was cut into disc-shaped samples with 1,0 $\mathrm{mm}$ in thickness and surface area of $0,502 \mathrm{~cm}^{2}$. Afterwards, the cpTi samples were subjected to HPT process under a pressure of $7,8 \mathrm{GPa}$ at room temperature. The rotational speed was $0,2 \mathrm{rpm}$ and the number of rotations was 5. Sergueeva et al. [26] revealed that the microstructure of UFG cpTi is sufficiently homogeneous after HPT deformation under pressure of $5 \mathrm{GPa}$ up to 5 rotations at room temperature, and therefore, in this study cpTi samples were subjected to HPT process up to 5 rotations. The obtained samples of UFG cpTi were discshaped with smaller thickness $(0,7 \mathrm{~mm})$ and the same surface area compared to cpTi in the initial state.

Moreover, in order to analyze microstructure of $\mathrm{cpTi}$ before and after HPT process, optical microscope (OM) Carl Zeiss Opton Axioplan and scanning electron microscope (SEM) MIRA3 TESCAN were used. The SEM operated at an accelerating voltage of $20 \mathrm{keV}$.

After that, the samples were ground with silicon carbide ( $\mathrm{SiC}$ ) abrasive paper (up to 2000 grit). Ultimately, the samples were degreased with ethanol in an ultrasonic bath for 10 minutes and then rinsed with distilled water.

The electrolyte used in order to simulate the oral environment and to perform the electrochemical tests was an artificial saliva solution (Pharmacy Belgrade, Serbia) at $37{ }^{\circ} \mathrm{C}$. The samples were immersed in artificial saliva with $\mathrm{pH}$ value of 4,0 and 5,5 at $37{ }^{\circ} \mathrm{C}$. The initial $\mathrm{pH}$ value of artificial saliva solution was 6,8 and the acidic $\mathrm{pH}$ values were obtained by addition of hydrochloric acid. The composition of artificial saliva solution is shown in Tab. 2. Fresh solution was used for each experiment.

Table 2 Chemical composition of artificial saliva

\begin{tabular}{|c|c|}
\hline Component & Concentration $\left(\mathrm{MolL}^{-1}\right)$ \\
\hline $\mathrm{NaCl}$ & 0,0844 \\
\hline $\mathrm{KCl}$ & 0,1200 \\
\hline $\mathrm{MgCl}_{2} \times 6 \mathrm{H}_{2} \mathrm{O}$ & 0,0052 \\
\hline $\mathrm{CaCl}_{2} \times 2 \mathrm{H}_{2} \mathrm{O}$ & 0,0146 \\
\hline $\mathrm{Sorbitol}^{\mathrm{KH}_{2} \mathrm{PO}_{4}}$ & 0,3000 \\
\hline $\begin{array}{c}\text { Carboxymethylcellulose } \\
\text { Sodium }\end{array}$ & 0,0342 \\
\hline Water & 0,1000 \\
\hline
\end{tabular}

A three-electrode cell arrangement was used for electrochemical measurements; a saturated calomel electrode (SCE) as a reference, a platinum wire as a counter and cpTi (CG and UFG) as a working electrode. In order to form working electrode each cpTi sample was embedded into an epoxy resin. After surface preparation, each sample was immersed into artificial saliva solution 
for $30 \mathrm{~min}$ to achieve a steady open-circuit potential (OCP). Electrochemical measurements were performed using a Gamry Reference 600 potentiostat within a Faraday cage, at $37^{\circ} \mathrm{C} \pm 1{ }^{\circ} \mathrm{C}$.

EIS measurements were performed at OCP over a frequency range from 0,01 to $100000 \mathrm{~Hz}$ using sinusoidal AC voltage amplitude of $\pm 10 \mathrm{mV}$. Potentiodynamic polarization was carried out in the potential range of $\pm 0,250 \mathrm{~V}$ with respect to the OCP at a scan rate of $1,0 \mathrm{mV}$ $\mathrm{s}^{-1}$. In order to maintain a high statistical accuracy, all electrochemical measurements were repeated at least three times.

The equivalent circuit related to the data extracted from EIS test is presented in Fig. 2 [27, 28]. $R_{\Omega}, R_{\mathrm{b}}$ and $R_{\mathrm{p}}$ represent the resistances of the protective oxide layer on electrolyte, inner barrier layer and porous outer layer, respectively. On the other hand, $C P E_{\mathrm{b}}$ and $C P E_{\mathrm{p}}$ represent the elements with constant-phase angle which are dependent on the frequency. The $C P E_{\mathrm{b}}$ and $C P E_{\mathrm{p}}$ are often used instead of a capacitance of the inner barrier layer $C_{\mathrm{b}}$ and porous outer layer $C_{\mathrm{p}}$, respectively, at inhomogeneous area. The capacitance and $C P E$ relation can be presented in the following manner [28]:

$$
C_{\mathrm{b}}=\left(C P E \cdot R_{\Omega}^{-\left(n_{\mathrm{b}}-1\right)}\right) \frac{1}{n_{\mathrm{b}}},
$$

and

$$
C_{\mathrm{p}}=\left(C P E \cdot R_{\Omega}^{-\left(n_{\mathrm{p}}-1\right)}\right)^{\frac{1}{n_{\mathrm{p}}}}
$$

As can be seen, $C_{\mathrm{b}}$ and $C_{\mathrm{p}}$ depend on coefficient $n$, which has a value in the range from 0 to 1 . If $n=0$, then the $C P E$ is a resistor. The $n$ value of 0,5 represents a Warburg's impedance relating to the diffusion process, while $n=1$ shows a complete capacitance $C$ behavior. Resistance $R$, capacitance $C$, and the coefficient $n$ for both layers were determined by experimental data fitting.



Figure 2 The equivalent circuit used in electrochemical tests

\section{Results}

The characteristic microstructures of the examined materials are shown in Fig. 3. Fig. 3a shows equiaxed $\alpha$ grains in the cpTi microstructure. It should be mentioned that Ti has two allotropic modifications: $\alpha$ - the atoms are arranged in a hexagonal close-packed (hcp) array (up to $882,5^{\circ} \mathrm{C}$ ) and $\beta$ - the atoms are arranged in a bodycentered cubic (bcc) array (above $882,5^{\circ} \mathrm{C}$ ) [29]. Thus, the $\beta$-to- $\alpha$ transformation temperature of pure $\mathrm{Ti}$ either increases or decreases based on the nature of the alloying elements [29]. Accordingly, the $\beta$ phase is found only at high temperatures unless $\mathrm{Ti}$ is alloyed with other elements which maintain the $\beta$ phase at lower temperatures. The average grain size of CPTi in the initial state was about 15 $\mu \mathrm{m}$ (Fig. 3a), while the average grain size of HPTprocessed CPTi was about $270 \mathrm{~nm}$ (Fig. 3b) and therefore it can be argued that CPTi is in the category of UFG materials. As can be seen from the SEM micrographs, HPT progressively leads to the transformation of the initial structure into a new ultrafine structure upon continued straining. Similarly, Elias et al. [30] demonstrated that SPD is an effective way to produce an UFG structure of CPTi and found an almost equiaxed grain morphology. According to the same authors, the UFG structure has been produced by the breakup of the original grain microstructure and successive rotation of the subgrains into new ultrafine grains by the increase in angular misorientation between adjacent grains.

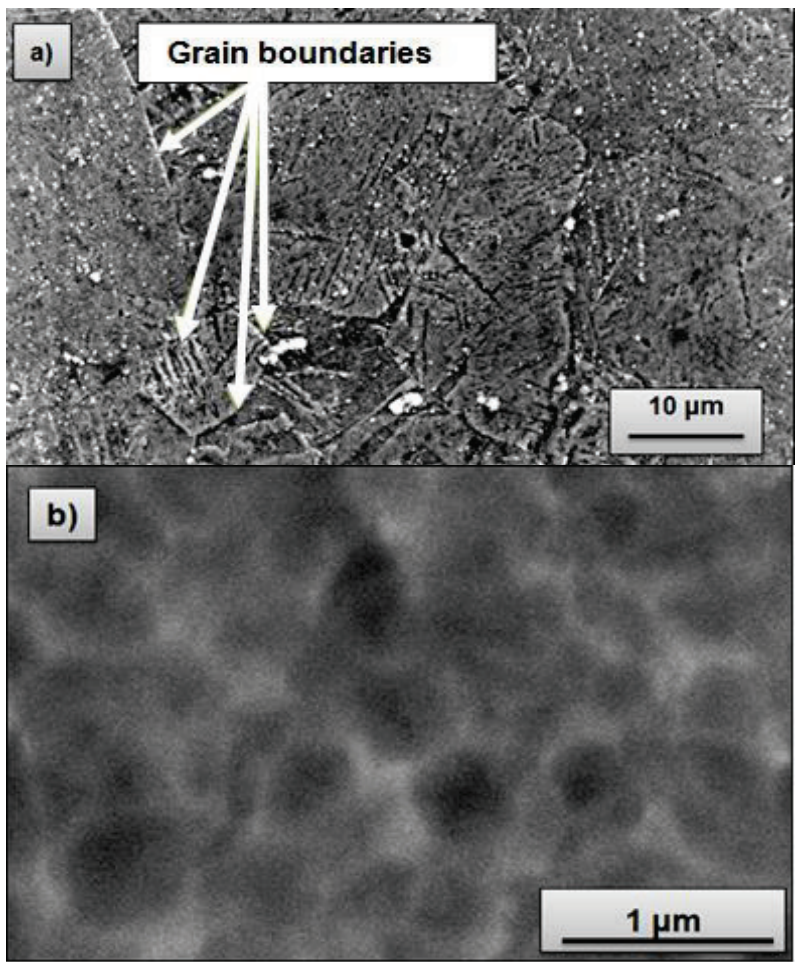

Figure 3 Microstructure of the examined materials: a) cpTi in the initial state, b) UFG cpTi

Anodic and cathodic polarization curves of the examined materials in artificial saliva with $\mathrm{pH}$ value of 4,0 and 5,5 are shown in Fig. 4. The corrosion potential, $E_{\text {corr }}$, and corrosion current density, $j_{\text {corr }}$, were obtained by Tafel analysis using both anodic and cathodic slope of the Tafel's curve. The determined values of these parameters are presented in Tab. 3. As can be seen in Figure 4 similar potentiodynamic curves were obtained for both materials. Material corrosion resistance can be evaluated using corrosion current density value, since it is commonly known that with its decreases material corrosion resistance increases. It can be observed that $j_{\text {corr }}$ is lower for UFG cpTi compared to CG counterpart in artificial saliva for both investigated $\mathrm{pH}$ values. In fact, $j_{\text {corr }}$ is relatively low for both materials (the order of $10^{-9}$ for $\mathrm{CG}$ cpTi and $10^{-10} \mathrm{Acm}^{-2}$ for UFG cpTi). This confirms that the examined materials are very resistant to corrosion in artificial saliva solution at $\mathrm{pH}$ of 4,0 and 5,5, regardless of 
whether they were processed by HPT or not. As can be seen in Tab. 3 , the corrosion current density is greater at $\mathrm{pH} 4,0$ than at 5.5; i.e. in acidic conditions. It can be also observed that the value of the $E_{\text {corr }}$ for the UFG cpTi and CG cpTi was more negative in the case of $\mathrm{pH}=5,5$ than in the case of $\mathrm{pH}=4,0$. Since $E_{\text {corr }}$ at the metal-electrolyte surface is closely dependent on various factors, such as temperature, $\mathrm{pH}$ value, surface of metal, the nature of metal, the environment or the electrodic reactions that take place [31,32], it can be concluded that magnitude of $E_{\text {corr }}$ is not a parameter that allows characterization of the corrosion phenomenon in a given system. In general, a lower potential metals are prone to more corrosion. But there is a possibility, when inhibition of cathodic reaction takes place due to quicker passivation, a displacement of this potential toward more negative values can occur [31]. However, less negative values of $E_{\text {corr }}$ of UFG cpTi obtained in this study indicate the formation of a stabile oxide layer and better corrosion resistance of UFG cpTi in artificial saliva compared to CG cpTi [32].

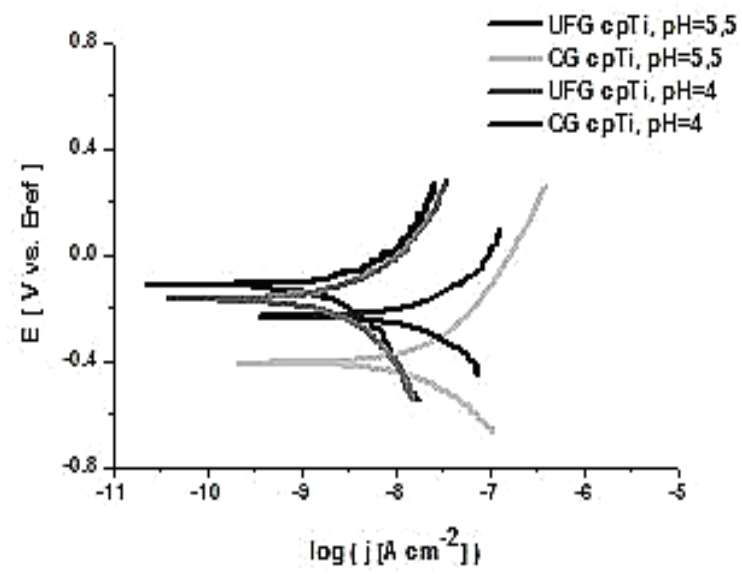

Figure 4 The potentiodynamic polarization curves of CG cpTi and UFG cpTi

Table 3 Electrochemical parameters of the examined materials

\begin{tabular}{|c|c|c|c|c|c|}
\hline Sample & $\mathrm{pH}$ & \multicolumn{4}{|c|}{ Parameters } \\
\hline & & $\begin{array}{c}E_{\text {corr }} \\
(\mathrm{V})\end{array}$ & $\begin{array}{c}j_{\text {corr }} \\
\left(\mathrm{nA} / \mathrm{cm}^{2}\right)\end{array}$ & $\begin{array}{c}b_{\mathrm{c}} \\
(\mathrm{mV} / \mathrm{dec})\end{array}$ & $\begin{array}{c}b_{\mathrm{a}} \\
(\mathrm{mV} / \mathrm{dec})\end{array}$ \\
\hline \multirow{2}{*}{ CG cpTi } & 4,0 & $-0,230$ & 3,08 & -90 & 45 \\
\cline { 2 - 6 } & 5,5 & $-0,409$ & 2,19 & -128 & 44 \\
\hline \multirow{2}{*}{ UFG cpTi } & 4,0 & $-0,113$ & 0,77 & -112 & 60 \\
\cline { 2 - 6 } & 5,5 & $-0,115$ & 0,59 & -127 & 46 \\
\hline
\end{tabular}

More details regarding thickness, compactness and stability of passive film are provided by the obtained EIS results. The impedance values are presented in a complex Nyquist and Bode planes. The Bode plots (impedance modulus $Z$ and phase angle $\theta$ as a function of frequency $f$ ) of the examined materials are shown in Fig. 5, while the Nyquist plots are shown in Fig. 6.

Bode plots show two time constants in different areas of frequency, for both materials, which is typical for twolayer oxide film. Namely, the protective oxide layer on titanium is made up of porous, outer layer and inner, barrier layer. The lower phase angle and lower modulus values indicate a lower resistance of passive oxide layer.

As can be clearly seen in Fig. 5, the phase angle for UFG cpTi is approximately $-75^{\circ}$ for both $\mathrm{pH}$ values, while CG cpTi shows the phase angle of $-60^{\circ}$ at $\mathrm{pH} 5,5$ and a little less at $\mathrm{pH} 4,0$. As can be seen in Fig. 6, $Z_{\text {imag }}$ and $Z_{\text {real }}$ values for UFG curves are higher than those of $\mathrm{CG}$ samples. Therefore, it can be concluded that CG cpTi shows lower corrosion resistance than UFG cpTi in artificial saliva, in $\mathrm{pH}$ values of 4,0 and 5,5. The difference in corrosion properties of CG and UFG cpTi is most probably related to the volume fraction of grain boundaries, as shown in study performed by MalekiGhaleh et al. [33].

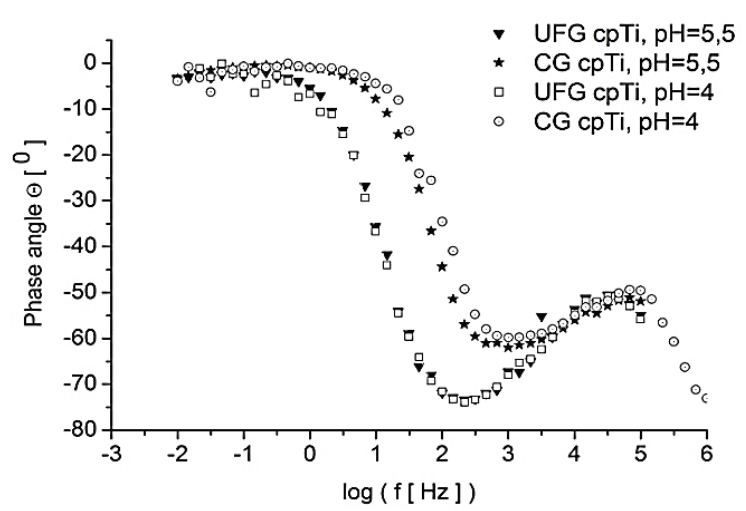

a)

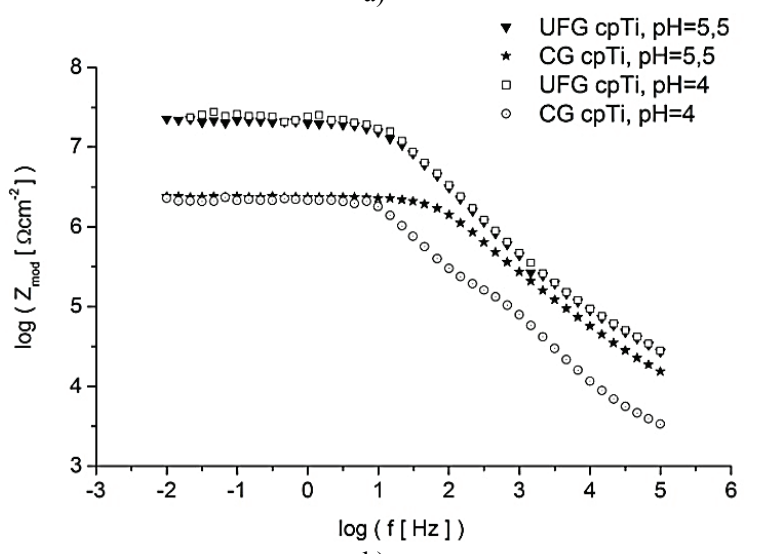

b)

Figure 5 The Bode phase angle diagrams (a) and Bode modulus diagrams (b)

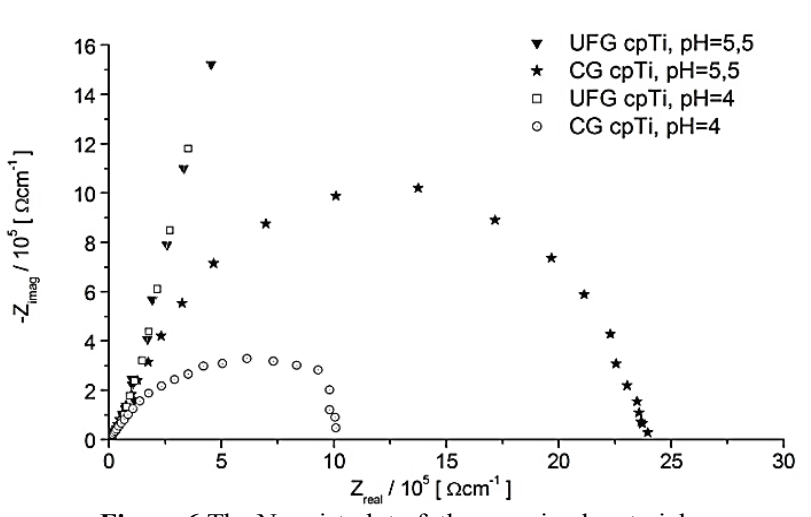

Figure 6 The Nyquist plot of the examined materials

As can be seen from Tab. 4, resistance of the inner compact barrier layer of passive film for investigated materials, $R_{\mathrm{b}}$, is larger than $10^{5} \Omega \mathrm{cm}^{2}$ and one or two orders greater than the resistance of the outer porous layer, indicating better protective properties of the barrier layer.

Also, the capacitance of the porous layer, $C_{\mathrm{p}}$, is higher than the capacitance of the barrier layer, $C_{\mathrm{b}}$. The passive film of UFG cpTi showed better barrier properties, in both 
$\mathrm{pH}$ conditions, compared to $\mathrm{CG}$ counterpart. This is indicated by high resistance $\left(R_{\mathrm{b}}\right.$ - the order of $\left.10^{7} \Omega \mathrm{cm}^{2}\right)$ and low capacitance $\left(C_{\mathrm{p}}\right.$ - the order of $\left.10^{-10} \mathrm{~S}^{n} \Omega^{-1} \mathrm{~cm}^{-2}\right)$. Also, it can be noticed that both materials showed lower corrosion resistance in the $\mathrm{pH}$ value of 4,0 ; i.e. in more acidic conditions.

The thickness of oxide layer, $d$, is inversely proportional to capacitance $C$, indicating as presented by the following equation [28]:

$$
C=\varepsilon \cdot \varepsilon_{0} \cdot \frac{A}{d},
$$

where $\varepsilon$ is the dielectric constant of oxide, $\varepsilon_{0}$ is dielectric permittivity of vacuum $\left(8,85 \times 10^{-12} \mathrm{~F} / \mathrm{m}\right)$, and $A$ is oxide layer surface.

Thus, the results shown in Table 4 indicate that oxide layer formed on UFG cpTi is of greater thickness than the one formed on CG cpTi. The resistance of the porous layer compared to resistance of the barrier layer is lower for both materials for one or two orders of magnitude, and the thickness of the outer porous layer of UFG cpTi is higher than that of CG cpTi in artificial saliva solution for both $\mathrm{pH}$ conditions.

Table 4 The electrochemical parameters - EIS data

\begin{tabular}{|l|l|c|c|c|c|}
\hline \multicolumn{2}{|l|}{ Material } & \multicolumn{2}{c|}{ CG cpTi } & \multicolumn{2}{c|}{ UFG cpTi } \\
\hline $\mathrm{pH}$ & 4,0 & 5,5 & 4,0 & 5,5 \\
\hline$R_{\mathrm{b}}\left(\Omega \mathrm{cm}^{2}\right)$ & $1,47 \times 10^{6}$ & $2,31 \times 10^{6}$ & $2,09 \times 10^{7}$ & $2,47 \times 10^{7}$ \\
\hline \multirow{2}{*}{$C P E_{\mathrm{b}}$} & $Y_{\mathrm{o}}\left(\mathrm{S}^{n} \Omega^{1} \mathrm{~cm}^{2}\right)$ & $2,50 \times 10^{-9}$ & $1,16 \times 10^{-9}$ & $5,54 \times 10^{-9}$ & $6,10 \times 10^{-10}$ \\
\cline { 2 - 6 } & $n$ & 0,80 & 0,85 & 0,89 & 0,90 \\
\hline \multicolumn{2}{|c|}{$R_{\mathrm{p}}\left(\Omega \mathrm{cm}^{2}\right)$} & $2,89 \times 10^{4}$ & $1,18 \times 10^{5}$ & $1,20 \times 10^{5}$ & $1,10 \times 10^{5}$ \\
\hline \multirow{2}{*}{$C P E_{\mathrm{p}}$} & $Y_{\mathrm{o}}\left(\mathrm{S}^{n} \Omega^{1} \mathrm{~cm}^{2}\right)$ & $7,96 \times 10^{-10}$ & $1,03 \times 10^{-9}$ & $4,64 \times 10^{-10}$ & $3,88 \times 10^{-10}$ \\
\cline { 2 - 6 } & $n$ & 0,822 & 0,86 & 0,85 & 0,873 \\
\hline
\end{tabular}

\section{Discussion}

From electrochemical measurements, which were performed in artificial saliva in $\mathrm{pH}$ of 4,0 and 5,5 at 37 ${ }^{\circ} \mathrm{C}$, in order to simulate oral environment, it can be concluded that the UFG cpTi material showed better barrier properties, and therefore, better corrosion resistance in respect to $\mathrm{CG}$ cpTi. Also, it can be noticed that the materials showed lower corrosion resistance in the $\mathrm{pH} 4,0$; i.e. in more acidic conditions.

For instance, Souza et al. [14] investigated electrochemical behavior of cpTi in Ringer physiological solution at two $\mathrm{pH}$ values $(5,5$ and 7,0$)$ and found that the $j_{\text {corr }}$ value is higher in more acidic solution. According to that study, the materials showed lower corrosion resistance in solution with $\mathrm{pH}$ value of 5,5 than in solution with $\mathrm{pH}$ value of 7,0. Qu et al. [34] analyzed the corrosion behavior of $\mathrm{cpTi}$ in artificial saliva with and without lactic acid and the corrosion resistance of cpTi showed a slight decrease with a decrease of the solution $\mathrm{pH}$ value. The corrosion of cpTi was distinctly affected by lactic acid presence and the corrosion rate increased with increasing the amount of lactic acid. Moreover, Balyanov et al. [35] investigated the corrosion behavior of cpTi with both UFG and CG microstructures and found that UFG cpTi produced by ECAP had better corrosion resistance than $\mathrm{CG}$ cpTi in both $\mathrm{HCl}$ and $\mathrm{H}_{2} \mathrm{SO}_{4}$ solutions. In addition, compared with CG cpTi, UFG cpTi had lower corrosion current densities, more positive corrosion potential, lower critical currents, $i_{c}$, at the passive potential, and more positive passive potential, $E_{p}$ value. Higher concentration of $\mathrm{HCl}$ or $\mathrm{H}_{2} \mathrm{SO}_{4}$ led to higher corrosion rates for both UFG and CG cpTi. Based on the available literature data one can conclude that the corrosion resistance of UFG cpTi is improved by rapid formation of passive films at surface crystalline defects, which include grain boundaries and dislocations [35]. Likewise, Balakrishnan et al. [32] analysed the UFG cpTi corrosion behavior produced by ECAP in simulated body fluid. Tafel extrapolation studies showed that the corrosion resistance of the UFG cpTi was 10 times higher compared to CG cpTi. In the similar way, Kim et al. [1] showed that annealed UFG cpTi obtained by high-ratio differential speed rolling (HRDSR) had better corrosion properties than annealed $\mathrm{CG}$ counterpart in $\mathrm{H}_{2} \mathrm{SO}_{4}$ solution. Contrary to these studies, Nie et al. [19] investigated electrochemical behavior of CG cpTI, which were annealed at $700{ }^{\circ} \mathrm{C}$ for $2 \mathrm{~h}$, and UFG cpTi, in $0,3 \%$ $\mathrm{NaCl}$ solution. Their analyses showed that corrosion resistance is lower for titanium after HPT process than for annealed CG cpTi.

Even though a number of papers engaged experimental analysis, which is a topic in this paper, a unique conclusion cannot be taken, but the majority of the obtained results indicated that UFG cpTi showed better corrosion resistance compared to its CG counterpart, in different media.

\section{Conclusion}

Results obtained in this study indicate that cpTi produced by HPT with UFG microstructure showed better corrosion resistance compared to $\mathrm{CG} \mathrm{cpTi}$, in artificial saliva for both $\mathrm{pH}$ values. In fact, high corrosion resistance of CG cpTi and UFG cpTi was indicated by very low corrosion current density. However corrosion current density was lower for UFG cpTi than for CG cpTi for both $\mathrm{pH}$ conditions, which indicate that UFG cpTi, with significant reduction of the grain size, showed higher corrosion resistance.

Also, in this study, UFG cpTi and CG cpTi demonstrated lower corrosion resistance in artificial saliva with $\mathrm{pH}$ value of 4,0 compared to $\mathrm{pH}$ value of 5.5 i.e. in more acidic solution. It should be mentioned that further examinations will include electrochemical testing of $\mathrm{CG}$ and UFG cpTi in different testing conditions (different temperature, presence of lactic acid and fluoride ions, etc.) in order to predict and better understand the behavior of these materials in the oral environment. 


\section{Acknowledgement}

The authors acknowledge the support from the Ministry of Education, Science and Technological Development of the Republic of Serbia through the project ON 174004. Also, the authors gratefully acknowledge prof. dr Reinhard Pippan and dr Anton Hohenwarter from Erich Scmid Institute of Material Science, Leoben - Austria, for the preparation of UFG samples and prof. dr Jelena Bajat (TMF, University of Belgrade) for her assistance in the electrochemical parameters analysis.

\section{References}

[1] Kim, H. S.; Kim, W. J. Annealing effects on the corrosion resistance of ultrafine-grained pure titanium. // Corrosion Science. 89, (2014), pp. 331-337. https://doi.org/10.1016/j.corsci.2014.08.017

[2] Čolić, K.; Sedmak, A.; Gubeljak, N.; Burzić, M.; Petronić, S. Experimental Analysis of Fracture Behaviour of Stainless Steel used for Biomedical Applications. // Structural Integrity and Life. 12, (2012), pp. 59-63.

[3] Özcan, M.; Hämmerle, C. Titanium as a reconstruction and implant material in dentistry: Advantages and pitfalls. // Materials. 5, (2012), pp. 1528-1545. https://doi.org/10.3390/ma5091528

[4] Ivušić, F.; Lahodny-Šarc, O.; Stojanović, I. Corrosion inhibition of carbon steel in saline solutions by gluconate,zinc sulphate and clay eluate. // Technical Gazette. 22, 1(2014), pp. 107-114.

[5] Rokosz, K.; Hryniewicz, T.; Raaen, S.; Valiček, J. SEM/EDX, XPS, Corrosion and surface roughness characterization of AISI 316L SS after electrochemical treatment in concentrated HNO3. // Technical Gazette. 22, 1(2015), pp. 125-131. https://doi.org/10.17559/TV-20140211130812

[6] Kozak, D.; Ivandić, V.; Konjatić, P. Determination of the critical pressure for ahot-water pipe with a corrosion defect. // Materials and Technology. 44, 6(2010), pp. 385-390.

[7] Nava - Dino, C. G.; López-Meléndez, C.; BautistaMargulis, R. G.; Neri-Flores, M. A.; Chacón-Nava, J. G.; D. de la Torre, S.; Gonzalez-Rodriguez, J. G.; MartínezVillafa-e, A. Corrosion Behavior of Ti-6Al-4V Alloys. // International Journal of Electrochemical Science. 7, (2012), pp. 2389-2402.

[8] Geetha, M.; Singh, A. K.; Asokamani, R.; Gogia, A. K. Ti based biomaterials, the ultimate choice for orthopaedic implants-a review. // Progress in Material Science. 54, (2009), pp. 397-425. https://doi.org/10.1016/j.pmatsci.2008.06.004

[9] Choubey, A.; Basu, B.; Balasubramaniam, R. Electrochemical behavior of Ti-based alloys in simulated human body fluid environment. // Trends in Biomaterial and Artificial Organs. 18, (2005), pp. 64-72.

[10] Assis, S.L.; Rogero, S.O.; Antunes, R.A.; Padilha, A.F.; Costa, I. A comparative study of the in vitro corrosion behavior and cytotoxicity of a superferritic stainless steel, a Ti-13Nb-13Zr alloy, and an austenitic stainless steel in Hank's solution. // Journal of Biomedical Materials Research: Part B Applied Biomaterials. 73, (2005), pp. 109116. https://doi.org/10.1002/jbm.b.30205

[11] Cvijović-Alagić, I.; Rakin, M. Integrity of biomedical implants of titanium alloys (first part). // Structural Integrity and Life. 8, (2008), pp. 31-40.

[12] Cvijović-Alagić, I.; Rakin, M. Integrity of biomedical implants of titanium alloys (second part). // Structural Integrity and Life. 8, (2008), pp. 121-130.
[13] Cvijović-Alagić, I.; Cvijović, Z.; Bajat, J.; Rakin, M. Composition and processing effects on the electrochemical characteristics of biomedical titanium alloys. // Corrosion Science. 83, (2014), pp. 245-154. https://doi.org/10.1016/j.corsci.2014.02.017

[14] Souza, M. E. P.; Lima, L.; Lima, C. R. P.; Zavaglia, C.A.C.; Freire, C. M. A. Effects of $\mathrm{pH}$ on the electrochemical behavior of titanium alloys for implant applications. // Journal of Materials Science: Materials in Medicine. 20, (2009), pp. 549-552. https://doi.org/10.1007/s10856-008-3623-y

[15] Li, Y.; Yang, C.; Zhao, H.; Qu, S.; Li, X.; Li, Y. New developments of Ti-based alloys for biomedical applications. // Materials. 7, (2014), pp. 1709-1800. https://doi.org/10.3390/ma7031709

[16] Estrin, Y.; Vinogradov, A. Extreme grain refinement by severe plastic deformation: A wealth of challenging science. // Acta Materialia. 61, (2013), pp. 782-817. https://doi.org/10.1016/j.actamat.2012.10.038

[17] Miran, S. Severe plastic deformation methods to achieve nanostructured materials. // International Journal of Material Science. 4, (2014), pp. 98-103. https://doi.org/10.14355/ijmsci.2014.0403.02

[18] Zhu, Y. T.; Lowe, T. C.; Langdon, T. G. Performance and applications of nanostructured materials produced by severe plastic deformation. // Scripta Materialia. 51, (2004), pp. 825-830. https://doi.org/10.1016/j.scriptamat.2004.05.006

[19] Nie, M.; Wang, Ch. T.; Qu, M.; Gao, N.; Wharton, J. A.; Langdon, T. G. The corrosion behaviour of commercial purity titanium processed by high-pressure torsion. // Journal of Material Science. 49, (2014), pp. 2824-2831. https://doi.org/10.1007/s10853-013-7988-z

[20] Shirooyeh, M.; Xu, J.; Langdon, T. G. Microhardness evolution and mechanical characteristics of commercial purity titanium processed by high-pressure torsion. // Materials Science and Engineering: A. 614, (2014), pp. 223-231. https://doi.org/10.1016/j.msea.2014.07.030

[21] Edalati, K.; Daio, T.; Arita, M.; Lee, S.; Horita, Z.; Togo, A.; Tanaka, I. High-pressure torsion of titanium at cryogenic and room temperatures: Grain size effect on allotropic phase transformations. // Acta Materialia. 68, (2014), pp. 207-213. https://doi.org/10.1016/j.actamat.2014.01.037

[22] Amirkhanova, N. A.; Valiev, R. Z.; Chernyaeva, E. Y.; Yakushina, E. B.; Semenova, I. P. Corrosion Behavior of Titanium Materials with an Ultrafine-Grained Structure. // Russian Metallurgy (Metally). 5, (2010), pp. 456-460. https://doi.org/10.1134/S0036029510050174

[23] Rajendran, S.; Paulraj, J.; Rengan, P.; Jeyasundari, J.; Manivannan, M. Corrosion behaviour of metals in artificial saliva in presence of spirulina powder. // Journal of Dentistry and Oral Hygiene. 1, (2009), pp. 1-8.

[24] Mary, S. J.; Rajendran, S. Corrosion behaviour of metals in artificial body fluid - an over view. // Materials Protection. 3, (2012), pp. 181-189.

[25] Bernáthová, M.; Buršák, M. Properties of pure titanium and ultra fine grained titanium. // Metallurgy. 50, (2011), pp. 249-252.

[26] Sergueeva, A. V.; Stolyarov, V. V.; Valiev, R. Z.; Mukherjee, A. K. Advanced mechanical properties of pure titanium with ultrafine grained structure. // Scripta Materialia. 45, (2001), pp. 747-752. https://doi.org/10.1016/S1359-6462(01)01089-2

[27] Bhola, R.; Bhola, S. M.; Mishra, B.; Olson, D. L. Corrosion in Titanium Dental Implants/Prostheses - A Review. // Trends in Biomaterial and Artificial Organs. 25, (2011), pp. 34-46.

[28] Cvijović-Alagić, I. Damage and fracture resistance of titanium based alloys for medical application. // $\mathrm{PhD}$ Thesis 
(in Serbian), Faculty of Technology and Metallurgy, University of Belgrade, 2013.

[29] Brooks, C. R. Heat treatment, structure and properties of nonferrous alloys. American Society for Metals, Metals Park, Ohio, USA, 1982.

[30] Elias, C. N.; Meyers, M. A.; Valiev, R. Z.; Monteiro, S. N. Ultrafine grained titanium for biomedical applications: An overview of performance. // Journal of Materials Research and Technology. 2, (2013), pp. 340-350. https://doi.org/10.1016/j.jmrt.2013.07.003

[31] Krivian, L. Meaning and measurement of corrosion potential. // British Corrosion Journal. 26, (1991), pp.191194. https://doi.org/10.1179/000705991798269143

[32] Balakrishnan, A.; Lee, B. C.; Kim, T. N.; Panigrahi, B.B. Corrosion Behaviour of Ultra Fine Grained Titanium in Simulated Body Fluid for Implant Application. // Trends in Biomaterial and Artificial Organs. 22, (2008), pp. 58-64.

[33] Maleki-Ghaleh, H.; Hajizadeh, K.; Hadjizadeh, A.; Shakeri, M. S.; Alamdari Ghobadi, S.; Masoudfar, S.; Aghaie, E.; Javidi, M.; Zdunek, J.; Kurzydlowski, K. J. Electrochemical and Cellular Behavior of Ultrafine-Grained Titanium in Vitro. // Materials Science and Engineering: C. 39, (2014), pp. 299-304. https://doi.org/10.1016/j.msec.2014.03.001

[34] Qu, Q.; Wang, L.; Chen, Y.; Li, L.; He, Y.; Ding, Z. Corrosion Behavior of Titanium in Artificial Saliva by Lactic Acid. // Journal of Alloys and Compounds. 476, (2009), pp. 172-175.

[35] Balyanov, A.; Kutnyakova, J.; Amirkhanova, N. A.; Stolyarov, V. V.; Valiev, R. Z.; Liao, X. Z.; Zhao, Y. H.; Jiang, Y. B.; Xu, H. F.; Lowe, T. C.; Zhu, Y. T. Corrosion Resistance of Ultra Fine-Grained Ti. // Scripta Materialia. 51, (2004), pp. 225-229.

https://doi.org/10.1016/j.scriptamat.2004.04.011

\section{Authors' addresses}

Dragana Barjaktarević, master engineer of technology Faculty of Technology and Metallurgy, University of Belgrade, Karnegijeva 4, 11000 Belgrade Serbia

E-mail: draganabarjaktarevic@gmail.com

Ivana Dimić, master engineer of technology

Faculty of Technology and Metallurgy, University of Belgrade, Karnegijeva 4, 11000 Belgrade Serbia

E-mail: idimic@tmf.bg.ac.rs

dr Ivana Lj. Cvijović-Alagić, research associate Institute of Nuclear Sciences "Vinča", University of Belgrade, PO Box 522, 11001 Belgrade, Serbia

E-mail: ivanac@vinca.rs

dr Đorde N. Veljović, research associate

Faculty of Technology and Metallurgy, University of Belgrade, Karnegijeva 4, 11000 Belgrade Serbia

E-mail: djveljovic@tmf.bg.ac.rs

prof. dr Marko P. Rakin, full professor

Faculty of Technology and Metallurgy, University of Belgrade, Karnegijeva 4, 11000 Belgrade Serbia

E-mail: marko@tmf.bg.ac.rs 